D. L. Vasyliev ${ }^{1}$, orcid.org/0000-0001-6864-357X, V.F. Hankevych ${ }^{2}$, orcid.org/0000-0002-8535-6318, T.V. Moskalova ${ }^{2}$, orcid.org/0000-0002-5352-8891, O.V. Livak ${ }^{3}$, orcid.org/0000-0002-5552-6531
1 - Institute of Geotechnical Mechanics named by N. Poljakov, Dnipro, Ukraine

2 - Dnipro University of Technology, Dnipro, Ukraine

3 - Ukrainian State University of Chemical Technology, Dnipro, Ukraine, email: Roxiki@i.ua

\title{
THE CHARACTER OF DISRUPTION OF THE ROCKS SURFACE DURING RAPID COOLING
}

Purpose. The purpose of this study is investigation of the patterns of occurrence of the system of macro- and microcracks in the rocks during rapid cooling for their effective softening.

Methodology. The solution of the problem of crack system development is based on the fact that, as a result of rapid cooling in the surface layer of the rock, the tensile stresses are developed. The stretched layer acquires potential energy, depending on the modes of thermal influence and rock properties. At a certain point, the energy of the stretched layer starts to be spent on the formation of new surfaces of the growing system of macro- and microcracks.

Findings. A model of behavior of the surface layer of rocks in the conditions of thermal shock by cooling is proposed. This model takes into account the development of a fracture macrocrack system and a microcrack system that move in the layer behind the cooling front. The dependence has been obtained that allows determining the penetration depth of a macrocrack system in the rock depending on the thermal exposure regimes and the physical and mechanical properties of the rocks. The formation of a microcrack system in the stretched cooled surface layer which changes its strength properties is experimentally proved. It is shown that the system of macrocracks moves into the array with deceleration and penetrates into the rock deeper than the thickness of the cooled layer, while microcracks are formed within the extended cooled layer. It is shown that the penetration depth of the macrocrack system into the rock is practically independent of the mode of thermal shock by cooling and is determined by the physical and mechanical properties of the rock and the time of exposure. Increasing the potential energy of the stretched rock layer due to an increase in the temperature difference between heating and cooling ("toughening" of the thermal shock regime) leads mainly to an increase in the density of a cracking net on the rock surface.

Originality. For the first time the development of a crack system rather than a single crack in a rock during rapid cooling was considered. The model of the rock surface layer behavior under the conditions of rapid cooling is proposed. The geometric aspects of the initiation and propagation of a macrocrack system into the rock due to thermocycling loading are considered. The fact of initiation of a microcrack system along with macrocracks which change the strength properties of rock in the formation zone is proved.

Practical value. The analytical dependence is obtained that allows determining the penetration depth of a crack system in rocks as a result of thermal shock by cooling. This dependence makes it possible to estimate the size of the damaged by macro- and microcracks zone of a rock, as well as the degree of rock softening depending on its physical and mechanical properties and thermal shock modes of cooling. The results are used in real technological processes with thermocycling impact such as preparing rocks for mechanical destruction, hydraulic fracturing, loosening and explosive destruction.

Keywords: rock, thermal stresses, intensive cooling, macro- and microcrack system

Introduction. In the study on thermomechanical methods of rock destruction, based on preheating followed by mechanical loading, there are enough facts that indicate that softening by thermal action according to the scheme: heating - sharp cooling is also quite an effective way of softening. In many cases, it is more effective than just preheating.

So, Prof. G. Brodov, examining the change in the strength of rocks during heating, came to the conclusion that the rapid cooling of heated hard rocks also leads to an irreversible decrease in strength (Brodov, G.). In the study on compressive strength of rocks, which were subjected to heat treatment according to the heating - rapid cooling with water with temperature differences between heating and cooling at 200-400$600{ }^{\circ} \mathrm{C}$ he came to the conclusion that the strength decreases monotonously. For plagiogranite, strength decreases from 1.51 to 2.13 times, for coarse-grained monzogranite - from 1.75 to 3.53 times, for fine-grained granodiorite - from 2.26 to 2.53 times. At the same time, the author points out that the main reason for the rock strength decrease is phase transformations and irreversible processes in rocks, without revealing the essence of these processes.

The scientists of the Institute of Geotechnical Mechanics of the National Academy of Sciences of Ukraine formulated

(c) Vasyliev D. L., Hankevych V. F., Moskalova T. V., Livak O. V., 2020 the notion that during rapid cooling of heated rocks tensile stresses develop in them. Since the tensile strength of the rocks is an order of magnitude lower than the compressive strength, under certain conditions of intensive cooling (thermal shock) the macrocracks form on surfaces and grow deep into massif (Vakhalin, Yu. N., Trokhimets, N. Ya., Lyash, S. I.). The theory of a single crack development under thermocycling loading is also presented here. The idea of intensive cracking of rocks during cooling was tested and the studies were carried out in the mine named after Kirov of PO "Kryvbasruda". These investigations were made in the rocks of ferruginous quartzite with interlayers of hematite-martite hornfels with strength $f=$ $=12: 14$ on the scale of prof. M. M. Protodyakonov. To expand pre-drilled wells with a diameter of $0.135 \mathrm{~m}$, the walls of the initial wells were subjected to thermocyclic treatment prior to drilling: first, they were heated by an infrared emitter for 1 hour, and then they were sharply cooled with water for $6-10$ minutes. Subsequent mechanical expansion to diameters of 0.2:0.5 m showed an increase in drilling speed by $2.3: 3.5$ times and a decrease in fracture energy consumption up to 3.3 times compared to purely mechanical drilling (Moskalev, A. N., Pigida, E. Yu., Kerekilitsa, L. G., Vakhalin, Yu. N.).

Thus, the high efficiency of softening rocks by rapid cooling was confirmed, but the scientific basis of the choice of thermocycling exposure modes is not given in the work. 
Further studies showed that the effect of coolant on heated rocks causes the appearance of "honeycomb structure" macrocracks on the surface; also formulas were obtained that allow determining the parameters of the net of cracks on the rock surface depending on the heat treatment regimes and rock properties [1].

Currently, two questions remain open:

- the nature of a net of micro-crack development inside the rock;

- the effect of rapid cooling on the microcracking of the surface layer.

The study on these issues will enable the targeted use of thermal shock by cooling in various real technological processes of rock destruction.

Literature review. Currently, the study on the influence of thermal loads on the physicomechanical properties of rocks is being carried out in several areas related to solving specific problems: studying the stability of rocks during the design of nuclear waste storage facilities, studying the processes of coal gasification, heat production in geothermal sources, shale gas and oil production, development of methods for the destruction of rocks based on their preliminary weakening by thermal loads.

In the article [2] the influence of heat treatment on the strength and deformation parameters of granite was studied. It was shown that microcracking in granite begins to appear from a heating temperature of $T=400-600{ }^{\circ} \mathrm{C}$, and at $T=700$ $800{ }^{\circ} \mathrm{C}$ an active process of fusion of granite microcracks occurs, which has a significant effect on the deformation processes at given heating temperatures.

Similar results were obtained during tensile tests by the Brazilian method of sandstone heated to $T=25-800{ }^{\circ} \mathrm{C}$ [3].

It has been stated that when heated to $T=400{ }^{\circ} \mathrm{C}$ the strength of the rock gradually increases, and with higher heating, it drops sharply. In the tensile tests of Laurentian granite heated to $T=850{ }^{\circ} \mathrm{C}$, it was determined that the static tensile strength decreases with increasing temperature, while the dynamic tensile strength first increases and then decreases starting from the heating temperature $T=450{ }^{\circ} \mathrm{C}$ [4].

A significant increase in sandstone fracture was observed upon heating above $300{ }^{\circ} \mathrm{C}$ while heating to $300^{\circ} \mathrm{C}$ did not give rise to fracture growth [5].

Ambiguous rock behavior in temperature fields was noted in [6]. In many rocks, when heated to $T=200{ }^{\circ} \mathrm{C}$, the strength increases, and at the same time, there is a "transitional value" of temperatures, where the strength begins to decrease. Similar results were obtained in [7], where tests of claystone samples heated above $T=200$ to $T=1000^{\circ} \mathrm{C}$ for uniaxial and triaxial compression showed first an increase in strength when heated to $T=200{ }^{\circ} \mathrm{C}$, and then its decrease with higher heating.

The study on the effect of heating on the static viscosity of three sandstone varieties of Indian deposits showed an increase in fracture toughness when heated to $T=100{ }^{\circ} \mathrm{C}$, and then a gradual decrease in viscosity was observed with further heating [8].

An important geotechnological property of rocks is their permeability when the temperature changes. It is shown that when granite is heated from $T=100$ to $T=800{ }^{\circ} \mathrm{C}$, an exponential increase in equivalent permeability is observed due to the formation of microcracks and their coalescence under heating [9].

It should be noted that all of the above studies were carried out to create stationary temperature fields. All tests had their own peculiarities in measuring the strength during heating, and these studies cannot be directly used to study the physical and mechanical properties of rocks in unsteady temperature fields and, especially, under conditions of thermal shock or thermocycling exposure.

One of the important directions for research is an attempt to use thermal loads for the preliminary weakening of rocks in various technological processes of rock destruction.
In the work [10], the authors conducted studies to reduce the mechanical strength of rocks during drilling with diamond crowns using the pulse washing regime. It is shown that pulsed flushing of wells gives higher amplitudes of temperature fluctuations in the bottom sections compared to stationary flushing, due to which the mechanical strength of the rock being destroyed can decrease by an average of $12 \%$.

The generation of thermal energy at the bottom of a well during diamond drilling and its targeted use for thermal cycling of rock sections for softening is considered as one of the promising directions for increasing the efficiency of diamond drilling [11]. At the same time, thermal loads on the face rock according to the scheme: heating-rapid cooling under certain conditions can lead to cracking of the destructible layer and, as a result, increase the overall performance of the diamond tool as a whole [12].

Methods and technical means for the implementation of thermocyclic impact during diamond drilling are being developed [13].

Intensive cooling by a fan of rock samples heated to $T=1000{ }^{\circ} \mathrm{C}$, representing disks that are suitable for tensile strength testing by the "Brazilian" method, for many hard rocks led to the appearance of fracture cracks in the samples, only due to thermal stresses. And this occurs despite the fact that the temperature difference between heating and cooling was low $\left(T=100^{\circ} \mathrm{C}\right)$, plus the cooling intensity was low (far from thermal shock) [14].

Purpose. The study on the laws of crack and microcrack system development in rocks during rapid cooling is the goal of this research. To achieve this goal, it is necessary to solve the following tasks. For macrocracks, to determine the nature of the crack system distribution over the rock surface in the zone where the rapid cooling is applied, and then, as it cools, to find patterns of this system penetration into the massif, depending on the physicomechanical properties of the rocks and thermal loading conditions. For microcracks, to confirm or disprove the fact of the developed microcrack system formation in the zone of rapid cooling and to give analytical dependencies that allow calculating the geometric parameters of fracturing both on the surface of the rock and in-depth.

Unsolved aspects of the problem. During rapid cooling, discontinuous (shrink) stresses develop in the surface layer, which under certain conditions create a developed system of cracks in the rock, which can significantly affect the strength properties of the rocks. Until now, the issue of a crack system formation and development, its geometric aspects under conditions of rapid cooling have not been studied. The behavior of a single crack was investigated and only in terms of its penetration into the massif. The very mechanism of the developed system of crack formation relies on the fact that during rapid cooling in the surface layer of the rock, natural microcracks begin to grow, which merge into a specific system. If thermal shock is maintained for some time, then the surface system of formed macrocracks will begin to grow deeper into the massif with certain regularities. Therefore, in order to reveal the complete picture of fracture penetration into the rock volume, it is necessary to imagine how cracks are distributed along the surface, and how deep they penetrate into the massif. Moreover, there is an assumption that behind the thermal front which penetrates into the rock as a result of sudden cooling, the microdestruction front moves, which also changes the physical and mechanical properties of the rock. The question of the depth ratio of penetration zones of macro- and microcracks is also open. Understanding the laws governing the formation of a crack system in the rock volume will allow us to evaluate the effect of this fracture on the actual processes of rock destruction associated with preliminary thermocyclic processing of the massif.

Methods. An analytical solution to the problem of the development of a system of shrinkage cracks is based on the fact that as a result of rapid cooling in the surface layer of a certain 
thickness, shrinkage tensile stresses are developed. The stretched layer of the rock acquires potential energy, depending on the properties of the rock and cooling conditions. At a certain point in time, the energy of the stretched layer will be spent on the formation of new surfaces of the growing system of macrocracks.

To confirm the fact of the formation of a system of microcracks in the stretched layer, studies were carried out on drilling of wells with a diameter of $0.01 \mathrm{~m}$ with a diamond crown. The walls of the wells were pre-treated with thermal cycling with a temperature difference $\Delta T$ of 300 and $600{ }^{\circ} \mathrm{C}$. Drilling was carried out in granite by a crown with a diameter of $0.02 \mathrm{~m}$. Based on the change in drilling speed, it was concluded whether there is a developed system of microcracks after treatment by rapid cooling.

Results. Upon sharp cooling of the surface rock layer at the boundary of the half-space, tensile stresses occur parallel to the surface $\sigma_{x}=\sigma_{y}=\sigma_{*}, \sigma_{z}=0$. The depth of penetration of the "cold" temperature front into the rock at the initial moments of time can be estimated by the dependence (Dmitriev, A. P., Goncharov, S.A., Germanovich, L. N.)

$$
m=(a \cdot \tau)^{1 / 2},
$$

where $a$ is the thermal diffusivity; $\tau$ is exposure time with a coolant. If the temperature difference between the rock and the cooling medium is large enough (hundreds of degrees), then macro- and micro-destruction of the massif in the zone of a sharp changes in temperature should be expected.

The model of rock behavior may look as follows. Since the rock resistance to fracture is an order of magnitude lower than the resistance to compression, when creating a certain temperature $\Delta T$ and time $\tau$ conditions, the rock can be torn by macrocracks.

However, it should be expected that from the beginning of cooling to the appearance of macrocracks, along with the isotherm, a microdestruction wave will propagate into the rock, behind which there is a layer broken by microcracks, resting on an elastic foundation and rigidly adhered to the latter. The question of whether microcracking is formed in the rock layer and how it affects the elastic and thermal properties remains open, since test results of this kind are unknown, and there are no corresponding petrographic observations of cracks of the required scale.

Let us consider the energy prerequisites for the development of cracks in a cooled surface layer.

In the one-dimensional thermoelasticity problem for a half-space, each point of which is in a state of biaxial tension $\sigma_{x}=\sigma_{y}=\sigma_{*}, \sigma_{z}=0$, the specific elastic energy of a unit volume is determined by the dependence (Dmitriev, A. P., Goncharov, S.A., Germanovich, L. N.)

$$
u=\frac{(1-v)}{E} \cdot \sigma_{*}^{2},
$$

where $v$ is Poisson's ratio of the material; $E$ is Young's modulus.

The total elastic energy accumulated in the surface layer with depth $m$ and area $S$ is

$$
W=S \cdot \frac{(1-v)}{E} \cdot \int_{0}^{m} \sigma_{*}^{2}(z) \cdot d z .
$$

It was established that during rapid cooling, the surface of the rock is torn by a "honeycomb" fracture, extending deep into the rock. The size of the cracking cell is determined by the dependence [13]

$$
g=\frac{0.45 \cdot K^{2} \cdot \sigma_{c}^{2}}{\pi^{2} \cdot \sigma_{*}^{2} \cdot \sigma_{s}^{2}},
$$

where $K$ is the rock adhesion module; $\sigma_{c}$ is rock compressive strength; $\sigma_{*}$ is maximum tensile stresses occurring in the rock at a given cooling mode; $\sigma_{s}$ is tensile strength of the rock.
In its turn

$$
K=\sqrt{\pi \cdot E \cdot \gamma},
$$

where $\gamma$ is the specific surface energy of rock destruction;

$$
\sigma_{*}=\frac{\beta \cdot E \cdot\left(T_{h}-T_{c}\right)}{1-v},
$$

where $\beta$ is the coefficient of linear expansion of the breed; $T_{h}$ is the initial rock temperature (after heating); $T_{c}$ is the temperature of the cooling medium.

In real cases, the rock is torn by a "cellular" fracture, in which the cells have a 4-5 or 6-angled shape. In the work (Steinhaus, G.) it is shown that the structures of cracks formed as a result of the action of shrink stresses have the shape of polygons with the number of sides no more than 6 . Therefore, in formula (4) we are talking about the equivalent (reduced) cell size of honeycomb, where the area of real cells is reduced to a square with an average area equal to the average area of real cells. In other words, the average equivalent size of the destruction cell is determined as follows: the number $n$ of real cells per unit area $S$ is calculated and the equivalent size is determined by the formula $g_{e}=\sqrt{\frac{S}{n}}$. Such a replacement leads to a certain decrease in the density of the net of cracks since a hexagon of the same square area has a perimeter of almost $40 \%$ more than a perimeter of a square. Considering the fact that along with hexagons in the net of cracks there are quadrangles and pentagons, the total increase in the perimeter of the net of cracks, in our estimation, does not exceed $20 \%$. At the same time, the strength of the cracked material is naturally overestimated. To clarify the general picture of the behavior of the system of cracks under conditions of rapid cooling, such assumptions, in our opinion, are quite justified, taking into account the significant simplification of further calculations.

Schematic reduction of a real net of cracks to an equivalent net of cracks is shown in Fig. 1.

With a rapid cooling of the rock surface, at some point in time the elastic energy of a thin stretched layer will be spent on the destruction of the rock (on the formation and development of cracks). If we assume that a wave of microdestructions follows the temperature front, then the general energy balance may look as follows.

$$
W=W_{n}+W_{m}+W_{f},
$$

where $W_{n}$ is the energy of formation of new surfaces of macrocracks; $W_{m}$ is microcracking energy; $W_{f}$ is the energy of plastic deformations and phase transitions in the rock.

Since the question of the formation of a developed system of microcracks at this stage of the study is open, we will assume that all the energy of the stressed layer will go into the energy of the formation and development of macrocracks. Then

$$
W=2 \cdot \gamma \cdot S_{c},
$$
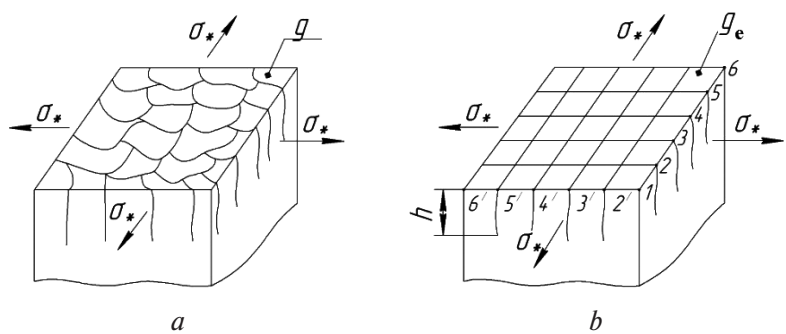

Fig. 1. The scheme of reduction of the real net of cracks on the surface of the rock to the equivalent during rapid cooling:

$a-a$ real picture of the net of cracks on the surface; $b$ - a picture of the equivalent net of cracks on the surface 
where $S_{c}$ is an area of newly formed cracks; coefficient " 2 " means that each crack gives two surfaces as a result of development.

The total elastic energy of the surface layer with an area $S$ and thickness $m$ after some time of exposure to the coolant, taking into account dependencies (1,2 and 3), will have the form

$$
W=S \cdot(a \cdot \tau)^{1 / 2} \cdot \frac{1-v}{E} \cdot \sigma_{*}^{2} .
$$

Under fairly severe cooling conditions (boundary conditions of the first kind or boundary conditions of the third kind, with a heat transfer coefficient $\alpha>10^{4} \mathrm{~W} / \mathrm{m}^{2} \cdot \mathrm{K}$ ), discontinuous thermal stresses in a thin surface layer of the rock are determined by dependence (6), therefore formula (9) for the total elastic energy in the rock layer has the form

$$
W=S \cdot(a \cdot \tau)^{1 / 2} \cdot \beta^{2} \cdot E \cdot \Delta T^{2} \cdot(1-v)^{-1},
$$

here $\Delta T=T_{h}-T_{c}$.

Let us estimate the total surface area $S_{c}$ of newly formed cracks in the cooling area $S$ according to the scheme (Fig. 1, b). The total length of cracks on the surface is defined as the total of longitudinal $1,2,3,4,5,6, \ldots, n$ and transverse $1^{\prime}, 2^{\prime}, 3^{\prime}, 4^{\prime}$, $5^{\prime}, 6^{\prime}, \ldots, n^{\prime}$ of straight cracks. On each side of the area $S$ the number of cracks will be greater by one than the number of cells with a size $g_{e}$ on this side. Assuming that the area $S$ is a square, the length of the side of the square (the same as the length of one longitudinal or transverse crack) will be equal $\sqrt{S}$, and the total number of longitudinal and transverse cracks will be expressed by the dependence

$$
n=2 \cdot\left(\frac{\sqrt{S}}{g_{e}}+1\right)
$$

The total length of cracks coming to the surface is

$$
L=2 \sqrt{S} \cdot\left(\frac{\sqrt{S}}{g_{e}}+1\right)
$$

and the area of newly formed cracks is estimated by the formula

$$
S_{T}=2 \cdot h \cdot \sqrt{S} \cdot\left(\frac{\sqrt{S}}{g_{e}}+1\right),
$$

where $h$ is the penetration depth of the system of cracks into the massif.

If we assume that all the accumulated elastic tensile energy of the rock layer will go to the formation of new crack surfaces, then taking into account dependences $(5,6$ and 7$)$ we obtain the equality

$$
S \cdot(a \cdot \tau)^{1 / 2} \cdot \beta^{2} \cdot E(\Delta T)^{2} \cdot(1-v)^{-1}=4 \cdot \gamma \cdot h \sqrt{S} \cdot\left(\frac{\sqrt{S}}{g_{e}}+1\right) .
$$

Hence, the penetration depth of cooling cracks in the array is determined by the formula

$$
h=\frac{\sqrt{S a \tau} \cdot \beta^{2} \cdot E(\Delta T)^{2}}{4 \gamma(1-v)\left(\frac{\sqrt{S}}{g_{e}}+1\right)} .
$$

Let us estimate the penetration depth $h$ of the "honeycomb" system of cracks and the average velocity $V$ of the motion of the fracture front in granite and glass during rapid cooling according to dependence (8).

In [14], experimental and theoretical values are given (calculated by the formula (4) of equivalent cells of cracks $g_{\text {? }}$ depending on the temperature difference $\Delta T$ during rapid cooling).
For granite: $g_{e}=2.5 \cdot 10^{-3} \mathrm{~m}(2.5 \mathrm{~mm})$ at DT $=335^{\circ} \mathrm{C}, g_{e}=$ $=2.5 \cdot 10^{-3} \mathrm{~m}(1.5 \mathrm{~mm})$ at $\Delta T=435^{\circ} \mathrm{C}$.

For glass: $g_{e}=2.5 \cdot 10^{-3} \mathrm{~m}(1.5 \mathrm{~mm})$ at $\Delta T=185^{\circ} \mathrm{C}, g_{e}=$ $=0.97 \cdot 10^{-3} \mathrm{~m}(0.97 \mathrm{~mm})$ at $\Delta T=235^{\circ} \mathrm{C}$.

Temperatures $\Delta T$ for glass are taken lower than for granite since, at higher temperatures heating in glass, the phenomena of thermoplasticity will play a significant role.

For calculation we take the value of the area of the cooling spot $S=25 \cdot 10^{-4} \mathrm{~m}^{2}\left(25 \mathrm{~cm}^{2}\right)$, the cooling time $\tau=0.5,1,5$, $10 \mathrm{~s}$.

Granite: $E=2.6 \cdot 10^{10} \mathrm{~N} / \mathrm{m}^{2} ; \beta=10^{-5} 1 / \mathrm{K} ; v=0.1 ; \gamma=$ $=3.5 \mathrm{~J} / \mathrm{m}^{2} ; a=8.3 \cdot 10^{-7} \mathrm{~m}^{2} / \mathrm{s}$.

Glass $E=10^{10} \mathrm{~N} / \mathrm{m}^{2} ; \beta=8 \cdot 10^{-6} 1 / \mathrm{K} ; v=0.2 ; \gamma=2.6 \mathrm{~J} / \mathrm{m}^{2} ;$ $a=5.3 \cdot 10^{-7} \mathrm{~m}^{2} / \mathrm{s}$.

The characteristics of granite and glass are taken from [15].

The calculation results are shown in Table 1.

For illustrative purposes, Figs. 2-6 show, in addition to the dependences of the penetration depth of the crack system into granite and glass $h=f(\Delta T)$ on the difference in heating and cooling temperatures $\Delta T$, for exposure times $\tau=5 \mathrm{~s}$, the dependence of the specific energy of the stressed layer $u=$ $=f(\Delta T)$ on $\Delta T$, which is calculated by the formula and the dependence of the crushing degree of a surface by a crack system $d=f(\Delta T)$ on the temperature difference $\Delta T$. Wherein $d$ is determined as $d=1 / g$ ( $g$ is calculated by dependence (4)).

It should be noted that the specific energy of the stressed layer $U$ and the degree of crushing $d$ at each point $\Delta T$ in the graphs do not depend on the coolant exposure time and are determined by the value $\Delta T$. But the full energy of the stressed layer and, accordingly, the penetration depth of the crack system into the rock due to the transition of this energy to the formation of new fracture surfaces are, among other things, also functions of the exposure time of the coolant $\tau$.

The graphs show that an increase in the specific potential energy of the stressed layer leads to an increase in the degree of surface fragmentation by a net of cracks but practically does not affect the penetration depth of the net into the rock. That

\begin{tabular}{|c|c|c|c|c|c|}
\hline Breed & $\tau, \mathrm{s}$ & $\Delta T,{ }^{\circ} \mathrm{C}$ & $g_{e}, \mathrm{~mm}$ & $h, \mathrm{~mm}$ & $V, \mathrm{~mm} / \mathrm{s}$ \\
\hline \multirow[t]{8}{*}{ Granite } & 0.5 & \multirow[t]{4}{*}{335} & \multirow[t]{4}{*}{2.5} & 3.6 & 7.20 \\
\hline & 1 & & & 5.1 & 5.10 \\
\hline & 5 & & & 11.4 & 2.28 \\
\hline & 10 & & & 16.1 & 1.61 \\
\hline & 0.5 & \multirow[t]{4}{*}{435} & \multirow[t]{4}{*}{1.5} & 3.7 & 7.40 \\
\hline & 1 & & & 5.3 & 5.30 \\
\hline & 5 & & & 11.9 & 2.38 \\
\hline & 10 & & & 16.8 & 1.68 \\
\hline \multirow[t]{8}{*}{ Glass } & 0.5 & \multirow[t]{4}{*}{185} & \multirow[t]{4}{*}{1.5} & 1.9 & 3.8 \\
\hline & 1 & & & 2.8 & 2.8 \\
\hline & 5 & & & 6.3 & 1.26 \\
\hline & 10 & & & 8.8 & 0.88 \\
\hline & 0.5 & \multirow[t]{4}{*}{235} & \multirow[t]{4}{*}{0.97} & 2.0 & 4.00 \\
\hline & 1 & & & 2.9 & 2.90 \\
\hline & 5 & & & 6.5 & 1.30 \\
\hline & 10 & & & 9.1 & 0.91 \\
\hline
\end{tabular}
is, almost, as though the additional tensile energy obtained by increasing $\Delta T$, is spent mainly on crushing the surface with a smaller system of cracks and does not affect the degree of pen-

Table 1

The penetration depth of the cracks system into granite and glass during rapid cooling 


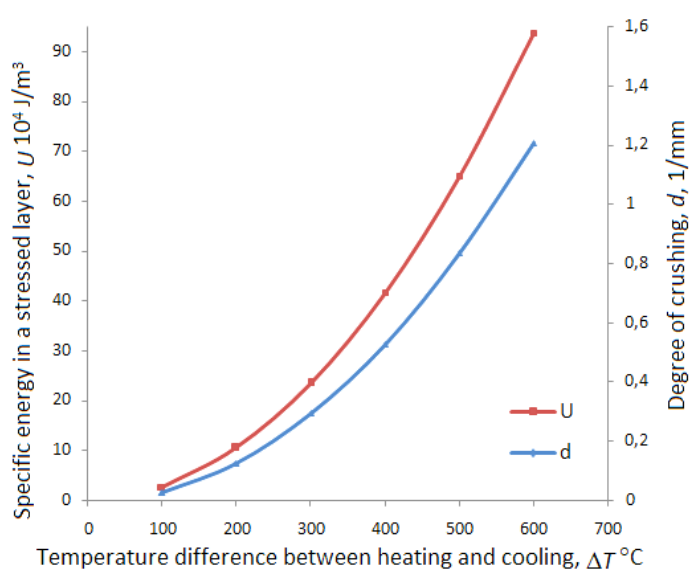

Fig. 2. Dependence of the crushing degree and specific energy in a stressed layer on the difference in heating and cooling temperatures for granite

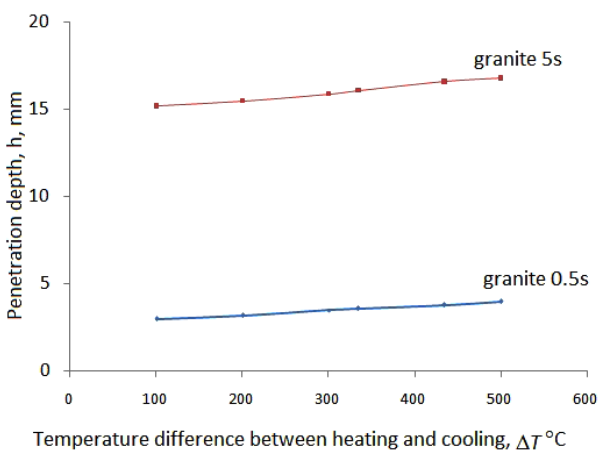

Fig. 3. Dependence of the penetration depth of a crack system into granite on the time of coolant exposure $\tau=0.5 \mathrm{~s}, \tau=5 \mathrm{~s}$

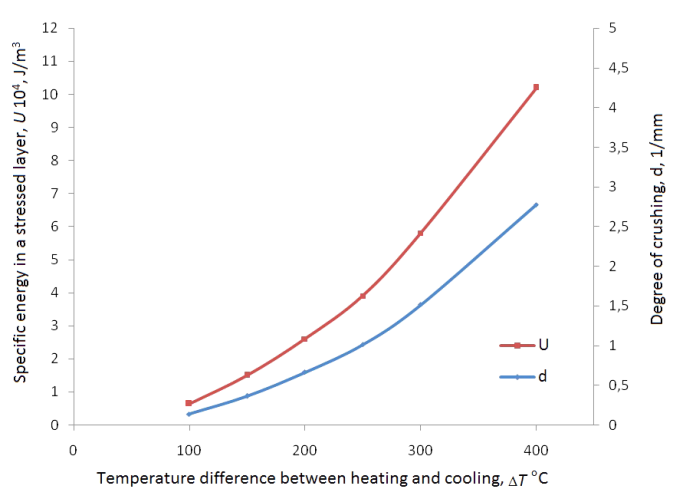

Fig. 4. Dependence of the crushing degree and specific energy in a stressed layer on the difference in heating and cooling temperatures for glass

etration of the fracture into the rock. Fig. 6 shows the dependencies of penetration depth of the cracks into the rock, depending on the time of coolant exposure for granite and glass. From the graphs, it follows that shrinkage cooling cracks move into the massif with deceleration.

Analysis of the material allows us to draw the following preliminary conclusions:

- during rapid cooling of the rock surface, the elastic potential tensile energy is accumulated in the cooled layer;

- with the increase in cooling time, the thickness of the stressed layer increases and, accordingly, the amount of stored energy increases;

- an increase in the temperature difference $\Delta T$ between the rock and the coolant, ceteris paribus, leads to an increase in the stored energy in the stressed layer;

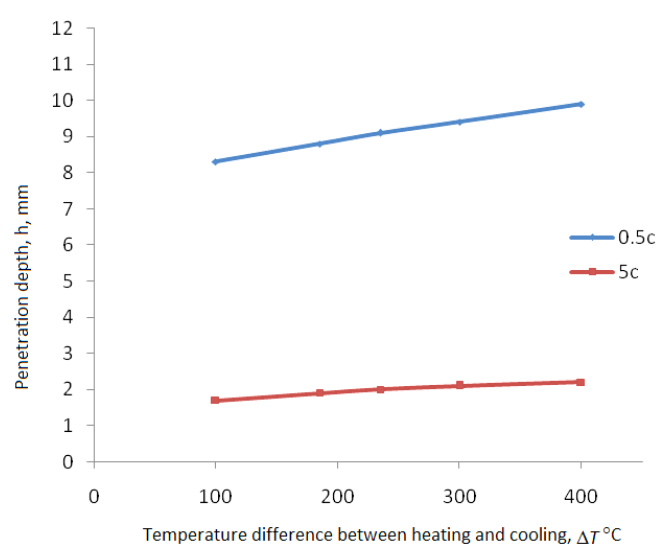

Fig. 5. Dependence of the penetration depth of a crack system into the glass on the time of coolant exposure $\tau=0.5 \mathrm{~s}, \tau=5 \mathrm{~s}$

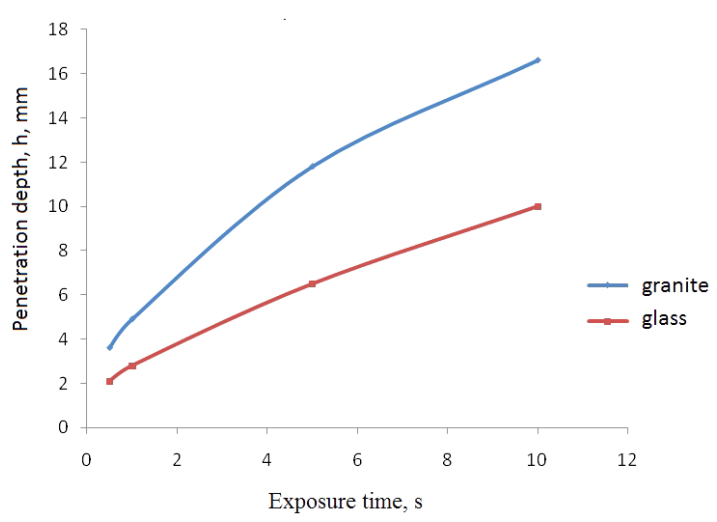

Fig. 6. Dependence of the penetration depth $h$ of the crack system into the rock and glass on the exposure time

- under certain conditions, the accumulated tensile energy begins to be spent on the formation of a net of cracks of a "honeycomb" structure growing deep into the massif;

- an increase in the energy of the stressed layer by raising the temperature difference $\Delta T$, ceteris paribus, hardly affects the penetration depth of the cracks net into the rock and the speed of advancement of the cracking front. All "additional" energy is spent on finer crushing of the rock by a net of macrocracks;

- cooling cracks move into the rock with a deceleration;

- the penetration depth of cracks in the massif exceeds the depth of the cooled rock layer, so in granite, after 1s of cooling at $\Delta T=435^{\circ} \mathrm{C}$ the thermal front, according to dependence (1), deepens by $0.91 \mathrm{~mm}$, and the cracks penetrate to a depth of $5.3 \mathrm{~mm}$ (Table 1).

In the framework of the model under consideration, the question remains unclear: does microcracking develop in the field of tensile stresses appearing from rapid cooling? As mentioned earlier, the model of the behavior of the surface layer of rocks under thermal shock cooling involves not only macrocracking of the surface but also the formation of a developed system of microcracks in the stretched layer, that is, along with the temperature front, a microdestruction wave extends into the rock.

In order to confirm or refute this model, the following experimental studies were carried out.

The idea was that if a microdestruction wave occurs during rapid cooling, then any subsequent small-scale mechanical failure should respond to the presence of microcracks. The main condition is that the size of the separated fractions of the material should be commensurate with the size of the newly formed microcracks. As mechanical destruction, diamond drilling was adopted with an impregnated small diameter crown. According to (Gorshkov, L. K., Gorelikov) the thickness of the chips removed by diamonds when cutting with a 
diamond crown is $0.16-0.03 \mathrm{~mm}$ for single-layer crowns and $0.1-0.02 \mathrm{~mm}$ for impregnated ones.

In accordance with the generally accepted classification, cracks with a size of $0.1: 0.01 \mathrm{~mm}$ are considered microcracks in the rock. Thus, the thickness of the removed chips is comparable with the magnitude of microcracks in the rock. Hence, if after surface treatment by rapid cooling there is a noticeable increase in drilling speeds, it means that a microdestruction wave accompanies the penetration of a "cold" heat front into the rock.

The experiments were carried out on samples of gray granite. In small blocks of at least $250 \times 250 \times 150 \mathrm{~mm}$ in size, holes with a diameter of $10 \mathrm{~mm}$ were drilled. Then the inner surface of the holes was subjected to heat treatment (heating-cooling). Heating parameters involve temperature 300 and $600{ }^{\circ} \mathrm{C}$, time $-30 \mathrm{~min}$.

After that, the walls of the wells were cooled in various modes: they were cooled in the air with the block, or immediately after heating they were washed with water at a temperature of $20{ }^{\circ} \mathrm{C}$ for $1 \mathrm{~min}$.

Thus, the walls of the wells were treated with thermocyclic treatment according to three schemes:

- heating to $600{ }^{\circ} \mathrm{C}$ and cooling in the air;

- heating to $300{ }^{\circ} \mathrm{C}$ and rapid cooling with water;

- heating up to $600{ }^{\circ} \mathrm{C}$ and rapid cooling with water.

The experimental results are shown in the Table 2 .

The analysis of the drilling results shows that thermocycling treatment leads to a decrease in the strength of granite. The main softening factor is the rapid cooling of the heated rock surface. Since diamond drilling is accompanied by a finegrained fracture of the rock, therefore, an increase in drilling efficiency after thermocycling treatment clearly indicates that the softening process is due to an increase in microcracking, the effect on pores, places of crystal adhesion, and others.

It can be argued that the proposed model of cracking of a rock layer by macro- and microcracks as a result of thermal shock cooling is confirmed.

The considered thermocyclic surface treatment of rocks can be used in various technological processes of drilling (in particular, diamond drilling) and expansion of wells, as well as in the preparation of wells for an explosion, hydraulic fracturing, injection of liquid, and so on.

Conclusions. The surface treatment of rocks by rapid cooling leads to the following:

- the surface of the rock is cracked by a "honeycomb" system of macrocracks. Cracks move into the massif with deceleration;

- the penetration depth of the macrocracks system depends mainly on the physicomechanical properties of the rocks and the cooling time and weakly depends on the temperature difference $\Delta T$ between the rock and the cooling medium;

- the crushing degree of the stressed rock layer by a macrocracks system is determined mainly by the temperature difference $\Delta T$;

- behind the front of the advancement of the cooled layer into the rock, a wave of microcracking of the rock moves;

- assessment of energy costs for microcracking requires additional studies, which will entail clarification of the dependence to determine the penetration depth of the macrocracks system into the rock during rapid cooling.

Table 2

The rate of expansion of wells treated with thermocyclic exposure

\begin{tabular}{|l|c|c|c|c|}
\hline $\begin{array}{c}\text { Type of processing } \\
\text { the walls of the well }\end{array}$ & $\begin{array}{c}\text { Wall heating } \\
\text { temperature, } \\
{ }^{\circ} \mathrm{C}\end{array}$ & $\begin{array}{c}\text { Type of } \\
\text { cooling }\end{array}$ & $\begin{array}{c}\text { Drilling } \\
\text { speed, } \\
\text { cm/min }\end{array}$ & $\begin{array}{c}\text { Drilling } \\
\text { speed } \\
\text { increase }\end{array}$ \\
\hline Without treatment & - & - & 1.90 & - \\
\hline Heating-cooling & 600 & Air & 2.28 & 1.2 \\
\hline Heating-cooling & 300 & Water & 2.66 & 1.4 \\
\hline Heating-cooling & 600 & Water & 3.99 & 2.1 \\
\hline
\end{tabular}

\section{References.}

1. Gankevych, V. F., \& Livak, O. V. (2017). Study on rock destruction processes using the temperature factor. Zbahachennia korysnykh kopalyn, (68), 46-55.

2. Yang, S. Q., Ranjith, P. G., Jing, H. W., Tian, W. L., \& Ju, Y. (2017). An experimental investigation on thermal damage and failure mechanical behavior of granite after exposure to different high temperature treatments. Geothermics, 65, 180-197. https://doi.org/10.1016/j.geothermics.2016.09.008.

3. Su, H., Jing, H., \& Du, M. (2016). Experimental investigation on tensile strength and its loading rate effect of sandstone after high temperature treatment. Arabian Journal of Geosciences, 9, 616. https://doi.org/10.1007/s12517-016-2639-8.

4. Yin, T., Li, X., \& Cao, W. (2015). Effects of Thermal Treatment on Tensile Strength of Laurentian Granite Using Brazilian Test. Rock Mechanics and Rock Engineering, (48), 22132223. https://doi.org/10.1007/s00603-015-0712-3.

5. Sun, Q., Zhang, W., \& Su, T. (2016). Variation of Wave Velocity and Porosity of Sandstone after High Temperature Heating. Acta Geophys. (64), 633-648. https://doi.org/10.1515/acgeo-2016-0021.

6. Wong, L. N. Y., Zhang, Y., \& Wu, Z. (2020). Rock strengthening or weakening upon heating in the mild temperature range? Engineering Geology, (272). https://doi.org/10.1016/j. enggeo.2020.105619.

7. Tian, H., Ziegler, M., \& Kempka, T. (2014). Physical and mechanical behavior of claystone exposed to temperatures up to $1000{ }^{\circ} \mathrm{C}$. International Journal of Rock Mechanics and Mining Sciences, (70), 144-153. https://doi.org/10.1016/j. ijrmms.2014.04.014.

8. Mahanta, B., Singh, T.A., \& Ranjith, P. G. (2016). Influence of thermal treatment on mode I fracture toughness of certain Indian rocks. Engineering Geology, (210), 103-114. https://doi.org/10.1016/i.enggeo.2016.06.008.

9. Yin, Q., Jing, H., \& Liu, R. (2020). Pore characteristics and nonlinear flow behaviors of granite exposed to high temperature. Bulletin of Engineering Geology and the Environment, (79), 1239-1257. https://doi.org/10.1007/s10064-019-01628-6.

10. Dreus, A. Yu., Sudakov, A. K., Kozhevnikov, A.A., \& Vakhalin, Yu. N. (2016). Study on thermal strength reduction of rock formation in the diamond core drilling process using pulse flushing mode. Naukovyi Visnyk Natsionalnoho Hirnychoho Universytetu, (3), 5-10.

11. Kozhevnikov, A. A., Dreus, A. Yu., \& Lee, B. (2017). The energy criterion of efficiency of diamond drilling with intermittent flush. Porodorazrushayushchiy $i$ metalloobrabatyvayushchiy instrument - tekhnika i tekhnologiya yego izgotovleniya i primeneniya: Sbornik nauchnykh trudov, (20), 62-66.

12. Kozhevnikov, A.A., \& Dreus, A.Yu. (2016). Analysis of the effectiveness of rock destruction during drilling with pulse flushing of wells. Porodorazrushayushchiy i metalloobrabatyvayushchiy instrument - tekhnika i tekhnologiya yego izgotovleniya i primeneniya: Sbornik nauchnykh trudov, (19), 62-66. http:// dspace.nbuv.gov.ua/handle/123456789/139102.

13. Kozhevnikov, A. O., Kravets', V. I., Vakhalin, Yu. M., \& Livak, O. V. (2018). Patent of Ukraine No. 125672. Ukraine.

14. Kim, K., Kemeny, J., \& Nickerson, M. (2014). Effect of Rapid Thermal Cooling on Mechanical Rock Properties. Rock Mechanics and Rock Engineering, (47), 2005-2019. https://doi. org/10.1007/s00603-013-0523-3.

15. Kozhevnikov, A.A., Krisan, V.V., Vakhalin, Yu. N., Tretiakov, O.A., \& Livak, O. V. (2011). Destruction of rocks during shock cooling: monograph. Dnipropetrovsk: Lizunov Press LLC. ISBN 978-966-2575-03-3.

\section{Характер руйнування поверхневого шару гірських порід при різкому охолодженні}

\section{Д. Л. Васильєв ${ }^{1}$, В. Ф. Ганкевич ${ }^{2}$, Т. В. Москальова², О. В. Лівак ${ }^{3}$}


1 - Інститут геотехнічної механіки імені Н. Полякова Національної академії наук України, м. Дніпро, Україна 2 - Національний технічний університет «Дніпровська політехніка», м. Дніпро, Україна

3 - Український державний хіміко-технологічний університет, м. Дніпро, Україна, e-mail: Roxiki@i.ua

Мета. Вивчення закономірностей розвитку системи макро- й мікротріщин у гірських породах при різкому охолодженні для ефективного знеміцнення гірських порід.

Методика. Вирішення питання щодо розвитку системи тріщин засноване на тому, що в результаті різкого охолодження в поверхневому шарі породи розвиваються напруження розтягу. Розтягнутий шар набуває потенційну енергію, залежну від режимів теплового впливу та властивостей породи. У певний момент часу енергія розтягнутого шару починає витрачатися на створення нових поверхонь зростаючої системи макро- й мікротріщин.

Результати. Запропонована модель поведінки поверхневого шару гірських порід в умовах термічного удару охолодженням, що припускає розвиток у породі системи макротріщин розриву й системи мікротріщин, що рухаються в шарі за фронтом охолодження. Отримана залежність, що дозволяє визначати глибину проникнення системи макротріщин у породу в залежності від режимів теплового впливу та фізико-механічних властивостей гірських порід. Експериментально доведено формування в розтягнутому охолодженому шарі системи мікротріщин, що змінюють властивості міцності порід у межах охолодженого шару. Показано, що система макротріщин рухається в масиві 3 уповільненням і проникає в породу глибше товщини охолодженого шару, а мікротрішини формуються в межах розтягнутого охолодженого шару. Показано, що глибина проникнення системи макротріщин у масив практично не залежить від режиму термоудару охолодженням і визначається фізико-механічними властивостями порід і часом впливу. Збільшення потенційної енергії розтягнутого шару породи за рахунок підвищення різниці температур між нагріванням і охолодженням («посилення» режиму термоудару) призводить, в основному, до збільшення ступеня дроблення породи сіткою тріщин.

Наукова новизна. Уперше розглянуто розвиток не одиночної тріщини в породі при різкому охолодженні, а системи тріщин. Запропонована модель поведінки поверхневого шару гірських порід в умовах різкого охолодження. Розглянуті геометричні аспекти формування й руху системи макротріщин у масив унаслідок термоциклічного навантаження. Доведено факт формування поряд із макротріщинами - системи мікротріщин, що змінюють властивості міцності порід у зоні формування.

Практична значимість. Встановлена аналітична залежність, що дозволяє визначати глибину проникнення системи тріщин у гірські породи в результаті термоудару охолодженням, i, як наслідок, оцінювати розміри зони ураження порід макро- й микротрешинами, а також ступінь знеміцнення гірських порід у залежності від фізикомеханічних властивостей і режимів термоудару охолодженням. Результати застосовуються при використанні термоциклічного впливу в реальних технологічних процесах: підготовки гірських порід до механічного руйнування, гідророзриву, розпушування, вибухового руйнування.

Ключові слова: гірська порода, термічні напруження, інтенсивне охолодження, система макро- й мікротріщин

\section{Характер разрушения поверхностного слоя горных пород при резком охлаждении}

\author{
Д. Л. Васильев ${ }^{1}$, В. Ф. Ганкевич², Т. В. Москалева ${ }^{2}$, \\ О. В. Ливак ${ }^{3}$
}

1 - Институт геотехнической механики имени Н. Полякова Национальной академии наук Украины, г. Днепр, Украина

2 - Национальный технический университет «Днепровская политехника», г. Днепр, Украина

3 - Украинский государственный химико-технологический университет, г. Днепр, Украина, e-mail: Roxiki@i.ua

Цель. Изучение закономерностей развития системы макро- и микротрещин в горных породах при резком охлаждении для эффективного разупрочнения горных пород.

Методика. Решение вопроса о развитии системы трещин основано на том, что в результате резкого охлаждения в поверхностном слое породы развиваются растягивающие напряжения. Растянутый слой приобретает потенциальную энергию, зависящую от режимов теплового воздействия и свойств породы. В определенный момент времени энергия растянутого слоя начинает расходоваться на образование новых поверхностей растущей системы макро- и микротрещин.

Результаты. Предложена модель поведения поверхностного слоя горных пород в условиях термического удара охлаждением, предполагающая развитие в породе системы макротрещин разрыва и системы микротрещин, движущихся в слое за фронтом охлаждения. Получена зависимость, позволяющая определять глубину проникновения системы макротрещин в породу в зависимости от режимов теплового воздействия и физико-механических свойств горных пород. Экспериментально доказано формирование в растянутом охлажденном слое системы микротрещин, меняющих прочностные свойства пород в пределах охлажденного слоя. Показано, что система макротрещин движется в массиве с замедлением и проникает в породу глубже толщины охлажденного слоя, а микротрещины формируются в пределах растянутого охлажденного слоя. Показано, что глубина проникновения системы макротрещин в массив практически не зависит от режима термоудара охлаждением и определяется физико-механическими свойствами пород и временем воздействия. Увеличение потенциальной энергии растянутого слоя породы за счет повышения разности температур между нагревом и охлаждением («ужесточение» режима термоудара) приводит, в основном, к увеличению степени дробления породы сеткой трещин.

Научная новизна. Впервые рассмотрено развитие не одиночной трещины в породе при резком охлаждении, а системы трещин. Предложена модель поведения поверхностного слоя горных пород в условиях резкого охлаждения. Рассмотрены геометрические аспекты формирования и движения системы макротрещин в массив вследствие термоциклического нагружения. Доказан факт формирования наряду с макротрещинами - системы микротрещин, меняющих прочностные свойства пород в зоне формирования.

Практическая значимость. Получена аналитическая зависимость, позволяющая определять глубину проникновения системы трещин в горные породы в результате термоудара охлаждением, и, как следствие, оценивать размеры зоны поражения пород макро- и микротрещинами, а также степень разупрочнения горных пород в зависимости от физико-механических свойств и режимов термоудара охлаждением. Результаты применяются при использования термоциклического воздействия в реальных технологических процессах: подготовки горных пород к механическому разрушению, гидроразрыва, рыхления, взрывного разрушения.

Ключевые слова: горная порода, термические напряжения, интенсивное охлаждение, система макро- и микротрещин

Recommended for publication by B. V. Vynohradov, Doctor of Technical Sciences. The manuscript was submitted 23.03.20. 